Bulletin of Environmental Contamination and Toxicology

March 2008, Volume 80, Number 3, Pages 283-288

http://dx.doi.org/10.1007/s00128-008-9364-2

(C) 2008 Springer. Part of Springer Science+Business

Media

The original publication is available at http://www.springerlink.com
Archimer, archive institutionnelle de l'ffremer http://www.ifremer.fr/docelec/

\title{
Monitoring of Trace Metal Contamination in the Souss Estuary (South Morocco) Using the Clams Cerastoderma edule and Scrobicularia plana
}

\author{
El Mehdi Anajjar ${ }^{1}$, Jean-François Chiffoleau ${ }^{2, *}$, Hafida Bergayou ${ }^{1}$, Abdelatif Moukrim ${ }^{1}$, Thierry \\ Burgeot $^{2}$ and Mohamed Cheggour ${ }^{3}$
}

\author{
${ }^{1}$ Laboratoire Eau et Environnement, Faculté des Sciences, Ibn Zohr university, B.P. 281S, Agadir, 80000, \\ Morocco \\ ${ }^{2}$ Biogeochemistry and Ecotoxicology Department, IFREMER, B.P. 21105, 44311 Nantes, cedex, France \\ ${ }^{3}$ Département de biologie, Unité d'Ecologie, Ecole Normale Supérieure, B.P. 2400, Marrakech, Morocco \\ *: Corresponding author : C. Chiffoleau, email address : Jean.Francois.Chiffoleau@ifremer.fr
}

\begin{abstract}
:
Concentrations of seven metals $(\mathrm{Cd}, \mathrm{Cu}, \mathrm{Cr}, \mathrm{Pb}, \mathrm{Ni}, \mathrm{Zn}, \mathrm{Hg})$ were monitored monthly during 2 years in two bivalves, Cerastoderma edule and Scrobicularia plana collected from the Souss estuary (South Morocco) before and after the commissioning of a sewage treatment plant in November 2002. According to trace metals, changes in concentrations were observed mainly in S. plana, characterised by a decrease of $\mathrm{Cu}, \mathrm{Hg}$ and $\mathrm{Pb}$ when $\mathrm{Cd}$ was clearly increasing. Conversely, no clear changes were observed in C. edule during the same periods. This study suggests the use of S. plana in the monitoring of trace metal contamination of such coastal marine environments.
\end{abstract}

Keywords: South estuary - Metals - Bivalves - Waste water - Monitoring

Bivalves molluscs are known from a long time to accumulate numerous contaminants at high levels in their tissues. That is one of the reasons why they are usually employed as sentinel species in monitoring programs of aquatic contamination (Phillips, 1980 ; Claisse, 1989 ; Bryan and Langston, 1992 ; Moukrim et al., 2000 ; Banaoui et al., 2003), considering that the contaminant loads in aquatic organisms would reflect their bioavailability and their impact on the environment. Although most of the monitoring studies are carried out using mussels, it is sometimes impossible to collect these species, particularly in non rocky environments. In this study, we focused on metallic contamination of two intertidal bivalves molluscs from the Souss estuary, Scrobicularia plana and Cerastoderma edule, that are ubiquitous in Moroccan 
Atlantic estuaries (Bergayou and Moukrim, 2005). These clams, as other bivalves, possess the main attributes that make them suitable as sentinels of chemical contamination in Moroccan environment (Cheggour et al., 2000, 2001, 2005). Moreover, they can be found on the European and African Atlantic coasts as well as in the Mediterranean, allowing comparative surveys. They both are living in fine sediments, and thus could reflect the sediment contamination, but they may provide complementary informations, as these clams don't have a similar diet. S. plana, usually living at a depth of $20 \mathrm{~cm}$ in fine sediment, is more a deposit feeder, especially at low tide, but also a filter feeder at high tide. In contrast, $C$. edule, usually encountered in the surface sediment, is mainly a suspension feeder by filtration, although it may occasionally use its siphons to collect nutritional particles from the mud flats (Jung et al., 2006).

The objective of this work is to use of these two species as bioindicators of the trace metal changes in the Souss estuary, which received large amounts of wastewater until 2002, when a sewage treatment plant was commissioned and the location of the wastewater discharge was moved to the coast (Ait Alla et al., 2006a). This study will complete another one dealing directly with the sediment contamination during the same period (Moukrim et al., submitted) and should largely contribute to the global study in this regional ecosystem (Gillet et al., 2003 ; Ait Alla et al., 2006a, 2006b ; Mouneyrac et al., 2005 ; Bergayou and Moukrim, 2005 ; Moukrim et al. 2000).

\section{MATERIALS AND METHODS}

The Souss estuary (Figure 1) has been largely described by Ait Alla et al., 2006a, 2006b. It is a southern basin in Morocco covering an area of $16.100 \mathrm{~km}^{2}$ and, particularly, the Souss plain which supports farming and industrial activities dominated by agricultural and chemical products. The city of Agadir, located along the two banks of the low stream zone, dumped a part of the domestic wastewaters in the estuary until 2002 (Ait Alla et al., 2006a). At that time, the great quantities of wastewaters discharged in the lower part of this river (which was dry during the most part of the year, receiving rainfall only during winter months) were often the single source of freshwater in the estuary. In November 2002, a wastewater purification plant was put in service and the resulting treated waters were discharged in M'Zar, a coastal site located at $3 \mathrm{~km}$ south. As a consequence, the nature of the estuarine waters have changed to dominantly marine ecosystem.

About 50 adult individuals for each species $(34.0 \pm 2.5 \mathrm{~mm}$ for $S$. plana and $25.0 \pm 2.5 \mathrm{~mm}$ for C.edule) were collected monthly during 2001 and 2003, before and after the wastewater discharge location was moved to the coast in 2002 in the lower estuary where now the marine effect prevails (Figure 1). The molluscs were rinsed in situ and maintained for $48 \mathrm{~h}$ in water from the sampling site to void the sediment-bound metals from the animal's gut. Then the clams were steel rinsed with distilled water and finally stored at $-30^{\circ} \mathrm{C}$ before metals analysis. Samples of molluscs were rinsed with double-distilled water and removed from their shells. The soft parts were dried at $60^{\circ} \mathrm{C}$ until a constant weight was obtained (at least for $12 \mathrm{~h}$ ) before being pooled and ground in an agate mortar. The evaluation of metal concentrations in the whole soft parts of the mollusc was made as described by Banaoui et al. (2004) : aliquots of $200 \mathrm{mg}$ of this powder were digested in Teflon bombs with $4 \mathrm{ml}$ of $\mathrm{HNO}_{3}$. Cadmium, copper, chromium, lead and nickel were analysed by graphite furnace (Varian, model AA 800 ) and $\mathrm{Zn}$ by air-acetylene flame (Varian, model AA 600) atomic absorption spectrophotometry. As $\mathrm{Hg}$ is volatile, its titration was performed using an automatic mercury analyser (ALTEC, model AMA 254). Quality assurance relies on the control of blanks and the 
accuracy and reproducibility of data relative to certified reference material (Table 1). In addition, participation in international intercomparison exercises (e.g. the EU QUASIMEME project) is done on a regular basis.

The clam's condition index (Lucas and Beninger, 1985) was determined as follows: CI = [(dry weight of soft masses) / (dry weight of valves)] x 1000. This index was calculated monthly for each species.

\section{RESULTS AND DISCUSSION}

Average metal concentrations in the clams for 2001 can be found in Figure 2. These values from the Souss estuary ranged within the values reported by Cheggour et al. (2000, 2001, 2005) in the same species from Moroccan lagoons and estuaries, and by Jung et al. (2006) in the $C$. edule compiled from different regions of the world. However, they were very low compared with those found in the $S$. plana living in a highly contaminated estuary, the estuary of Bilbao, Spain ( Ruiz and Saiz-Salinas, 2000), suggesting that the degree of contamination of the Souss estuary may be slight, compared to a highly contaminated estuary. Generally, the concentration of trace metals (Figure 2) is significantly higher in Scrobicularia plana than in Cerastoderma edule (case of $\mathrm{Cr}, \mathrm{Cu}, \mathrm{Hg}, \mathrm{Pb}$ and $\mathrm{Zn}$ ) although conversely the level of $\mathrm{Ni}$ is much larger in Cerastoderma edule. Only the levels of $\mathrm{Cd}$ are of the same order for the 2 species.

The metal concentrations and condition index (CI) measured for the 2 periods for each species are shown in Figures 3 and 4. Condition index shows a classic pattern in 2001 (Cheggour et al., 2005), characterised by a high level in winter and a loss of weight in spring and summer which is due to a typical biological cycle. However, the fluctuations recorded in 2003, of the same type but attenuated in Scrobicularia plana, show a clear difference in Cerastoderma edule, with apparently no decrease in spring. This could suggest anomalies in the biological cycle after stopping the inputs of effluents, and also the inputs of freshwater. These anomalies are also observed in the seasonal variations of trace metals (Figures 3 and 4) and will be discussed below.

In order to correct the trace metal variations from a natural effect (Mubiana et al., 2006), the relation with the condition index was studied. In 2001, the trace metal concentrations vary with the condition index in Cerastoderma edule (high levels in winter, lowest level in summer) except for mercury and nickel which doesn't seem related to the season (Figure 3). In contrast, the highest levels in Scrobicularia plana are noted generally in autumn $(\mathrm{Cd}, \mathrm{Cu}$, $\mathrm{Hg}, \mathrm{Pb}$ ) period when the index condition is the lowest (Figure 4). These comparable patterns between the condition index and the trace metal body burden suggest that before the commissioning of the treatment plant, the system was in equilibrium and that the seasonal trace metal variations were mainly influenced by the biological cycle of the living organisms. The situation is less clear in 2003, after stopping the effluents inputs. : In Cerastoderma edule, we observe some unexpected abrupt but short increases in trace metals $(\mathrm{Ni}, \mathrm{Hg}$ and $\mathrm{Pb}$ ), with the $\mathrm{Cr}$ values remaining very high throughout the summer. $\mathrm{Cu}$ and $\mathrm{Zn}$, and to some extent $\mathrm{Cd}$, the seasonal pattern in 2003 is comparable to that is 2001. In Scrobicularia plana (Figure 4), the key features described above for Cerastoderma edule are observed : the seasonal $\mathrm{Cr}$ cycle is highly disturbed during summer, and sharp increases in $\mathrm{Ni}$ and $\mathrm{Hg}$ (but later than $C$. edule). Furthermore, some peaks of $\mathrm{Cu}$ and $\mathrm{Zn}$ appear at the end of the summer ; only $\mathrm{Cd}$ could show a coherent seasonal behaviour in phase with the condition index, except that, in 2001, the Cd pattern was in opposite phase with the CI. 
Comparing the level of trace metal contamination before and after the commissioning of the sewage treatment plant, Cerastoderma edule doesn't show clear changes except for $\mathrm{Cr}$, which, as it was noted above, shows a high increase between July and September 2003. However, we can observe in Scrobicularia plana very clear changes for trace elements which exhibit a relationship with the condition index. Thus, Figure 5 shows a significant increase in $\mathrm{Cd}$ for the whole series of measurements $(\mathrm{p}<0.0001)$ when an important decrease is observed for $\mathrm{Cu}$ $(\mathrm{p}=0.002)$, for $\mathrm{Hg}(\mathrm{p}=0.0001)$ and for $\mathrm{Pb}(\mathrm{p}<0.00001)$. For the other trace elements, the variations are not significant. These observations suggest several comments : (1) Cerastoderma edule doesn't seem to be a good indicator for such monitoring activities, whereas Scrobicularia plana could be a good one. (2) As it was expected, the contamination of certain metals in this coastal organism has decreased after the removal of the sewage effluents. Nevertheless, this observation must be regarded carefully. It is known that the metal body burden of living organisms is generally a function of the bioavailable trace metals in the surrounding environment (Langston et al., 2003). In the present case, the environmental conditions have changed recently ( $\mathrm{pH}$ of the sediment, salinity, organic matter load) and the system might not be in steady state, as it was hypothesised above when studying the condition index pattern. In particular, an increase of $\mathrm{Cd}$ was not expected in the tissues of S. plana and could be due to the increase in salinity which is known to make the particulate Cd soluble to a great extent (Chiffoleau et al., 2001). As long as the Oued Souss sediment will be loaded with mobile $\mathrm{Cd}$, it is likely that the mollusc will exhibit $\mathrm{Cd}$ concentrations higher than before the commissioning of the treatment plant.

This 2-year study proved most helpful for the assessment of metal contamination in the Souss estuary; it also demonstrated that the choice of a bioindicator was paramount, and that ancillary parameters were essential to avoiding erroneous conclusions. Finally, it confirmed that the positive impact of depuration facilities on environmental contamination is not easily or immediately detectable in chronically-polluted areas.

\section{REFERENCES}

Ait Alla A, Gillet P, Deutsch B, Moukrim A, Bergayou H (2006a) Response of Nereis diversicolor (Polychaeta, Nereidae) populations to reduced wastewater discharge in the polluted estuary of Oued Souss, Bay of Agadir, Morocco. Estuar Coast Shelf Sci 70:633-642

Ait Alla A, Mouneyrac C, Durou C, Moukrim A, Pellerin J (2006b) Tolerance and biomarkers as useful tools for assessing environmental quality in the Oued Souss estuary (Bay of Agadir, Morocco). Comp Biochem Physiol C 143:23-29

Banaoui A, Chiffoleau JF, Moukrim A, Azdi M, Kaaya A, Auger D, Rozuel E (2004). Trace metal distribution in mussel Perna perna along the Moroccan coast. Mar Pollut Bull 48:378402

Bergayou H, Moukrim A (2005) Cerastoderma edule (Linné, 1758) et Scrobicularia plana (da Costa, 1778): étude comparative de la croissance des mollusques et des générations annuelles dans l'estuaire de l'Oued Souss (sud-ouest du Maroc) sous climat aride. Haliotis 34:49-58

Bryan GW, Langston WJ (1992) Bioavailability, accumulation and effects of heavy metals in sediments with special reference to United Kingdom estuaries. A review. Environ Pollut 76:89-131 
Cheggour M, Langston WJ, Chafik A, Texier H, Kaimoussi A, Bakkas S, Boumezzough A (2000) Metals in the bivalve molluscs Scrobicularia plana (Da Costa) and Cerastoderma edule (L.) and associated surface sediment from Oum Er Rbia Estuary (Moroccan Atlantic Coast). Toxicol Environ Chem 7:49-77

Cheggour M, Chafik A, Langston WJ, Burt GR, Benbrahim S, Texier H (2001) Metals in sediments and the edible cockle Cerastoderma edule from two Moroccan Atlantic lagoons: Moulay Bou Selham and Sidi Moussa. Environ Pollut 115:149-160

Cheggour M, Chafik A, Fisher NS, Benbrahim S (2005) Metal concentrations in sediments and clams in four Moroccan estuaries. Mar Environ Res 59:119-137

Chiffoleau JF, Auger D, Chartier E, Michel P, Truquet I, Ficht A, Gonzalez JL, Romaña LA (2001) Spatiotemporal changes in cadmium contamination in the Seine estuary (France). Estuaries 24:1029-1040

Claisse D (1989) Chemical contamination of French coast. The results of a ten years musselwatch. Mar Pollut Bull 20:523-528

Gillet P, Gorman E, Tallec A, Moukrim Z, Mouloud M, Ait Alla A, Bergayou H, Kaaya A (2003) Impact of city wastewaters on benthic intertidal communities in the mouth of the Souss Wadi, bay of Agadir (Morocco). J Rech Oceanogr 28:39-44

Jung K, Stelzenmüller V, Zauke GP (2006) Spatial distribution of heavy metal concentrations and biomass indices in Cerastoderma edule Linnaeus (1758) from the German Wadden Sea: An integrated biomonitoring approach. J Exp Mar Biol Ecol 338:81-95

Langston WJ, Chesman BS, Burt GR, McEvoy J, Pope ND (2003) Bioaccumulation of metals in the Thames Estuary. Environment Agency, Reading (UK). no. 8, $131 \mathrm{p}$

Lucas A, Beninger PG (1985) The use of physiological condition indices in marine bivalve aquaculture. Aquaculture 44: 187-200

Moukrim A, Kaaya A, Najimi S, Roméo M, Gnassia-Barelli M, Narbonne JF (2000). Assessment of the Trace Metals Level in Two Species of Mussels of the Agadir Marine Bay (south of Morocco). Bull Environ Contam Toxicol 65:478-485

Mouneyrac C, Pellerin J, Moukrim A, Ait Alla A, Durou C, Viault N (2005) In situ relationship between energy reserves and steroid hormone levels in Nereis diversicolor (O.F. Müller) from clean and contaminated sites. Ecotoxicol Environ Safe 65:181-187

Mubiana VK, Vercauteren K, Blust R (2006) The influence of body size, condition index and tidal exposure on the variability in metal bioaccumulation in Mytilus edulis Environ Pollut 144:272-279

Phillips DJH (1980) Quantitative aquatic biological indicators. Applied Science Publishers Ltd, London. 
Ruiz JM, Saiz-Salinas JL (2000) Extreme variation in the concentration of trace metals in the sediment and bivalves from the Bilbao estuary (Spain) caused by the 1989-90 drought. Mar Environ Res 49:307-317 


\section{FIGURE CAPTIONS}

Fig. 1 The Souss estuary with the sampling site and the main effluent of Agadir city (removed in 2002)

Fig. 2 Respective mean concentrations of trace metals (in $\mu \mathrm{g} \mathrm{g}^{-1}$ d.w.) in S. plana and C. edule in 2001

Fig. 3 Monthly variations of trace metals concentrations (in $\mu \mathrm{g} \mathrm{g}^{-1} \mathrm{~d}$.w.) and condition index in Cerastoderma edule

Fig. 4 Monthly variations of trace metals concentrations (in $\mu \mathrm{g} \mathrm{g}^{-1}$ d.w.) and condition index in Scrobicularia plana

Fig. 5 Distribution of trace metal $v s$ condition index in Scrobicularia plana

\section{LIST OF TABLES}

Table 1 Performances of the quality control with the CRM 278R from the BCR (Brussels) except for nickel where the CRM TORT-2 from the NRCC (Ottawa) was used. 


\section{Figure 1}

Click here to download Complete Manuscript (text, tables, and figures): Figure 1.doc

Figure 1

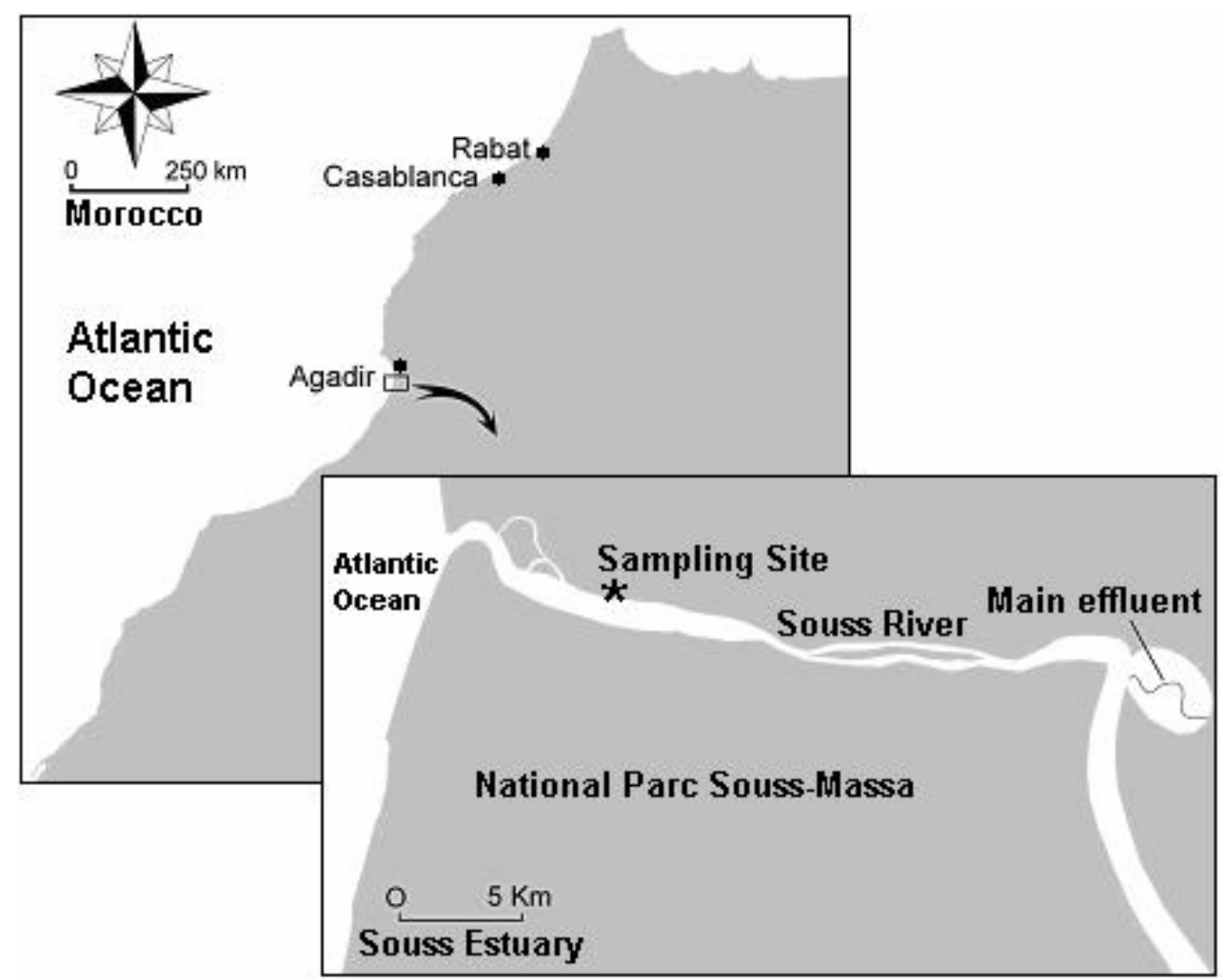


Click here to download Complete Manuscript (text, tables, and figures): figure 2.xls

Figure 2

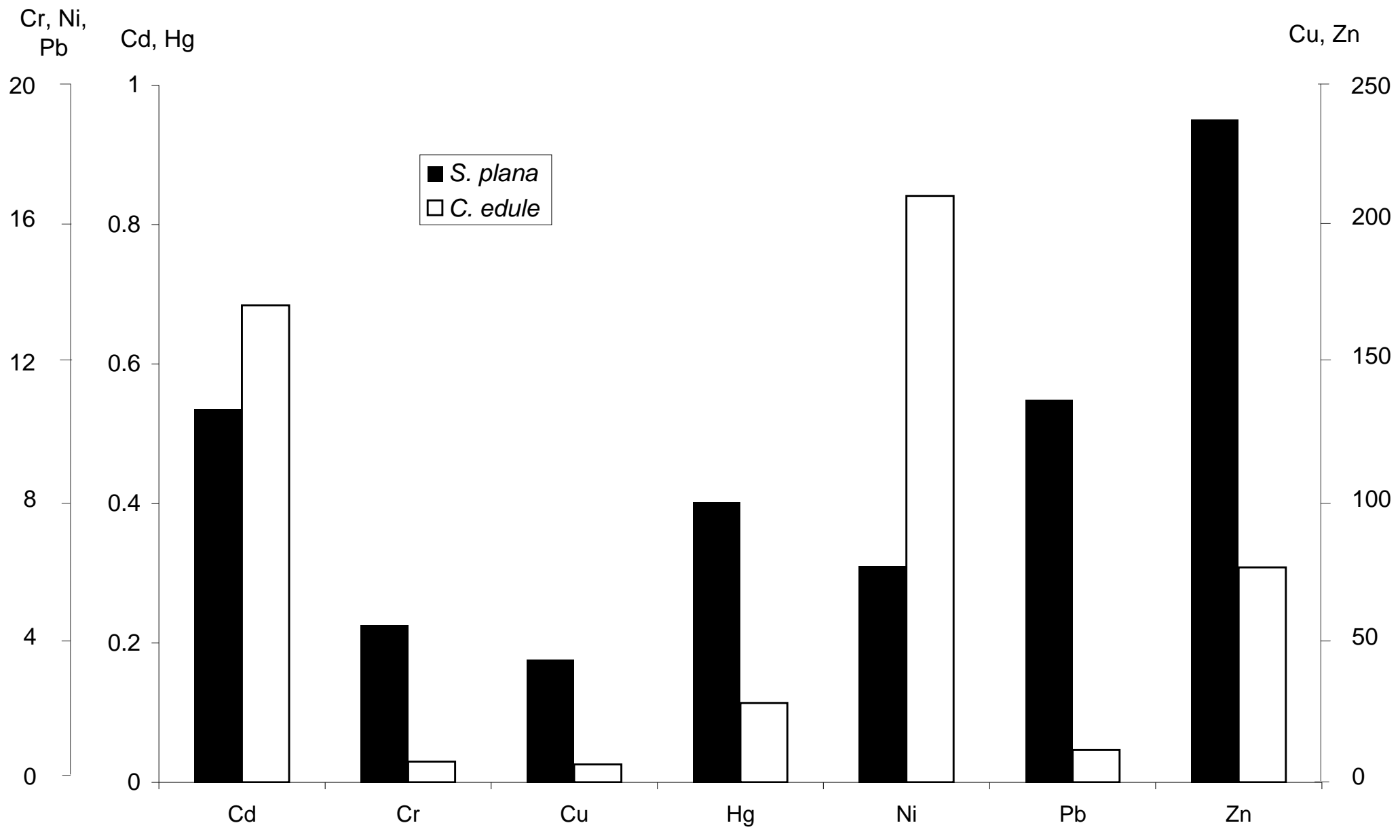


Figure 3
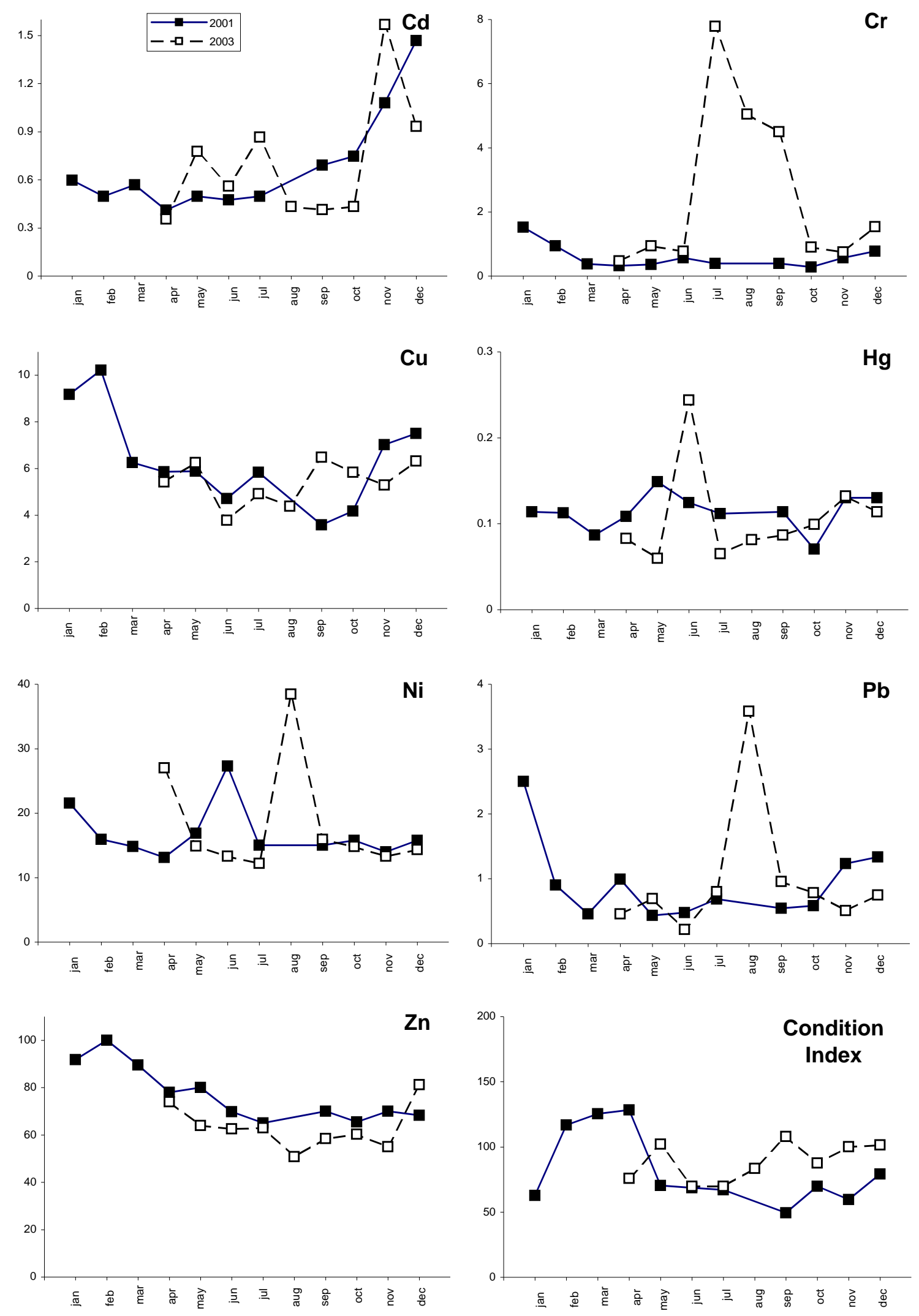
Figure 4
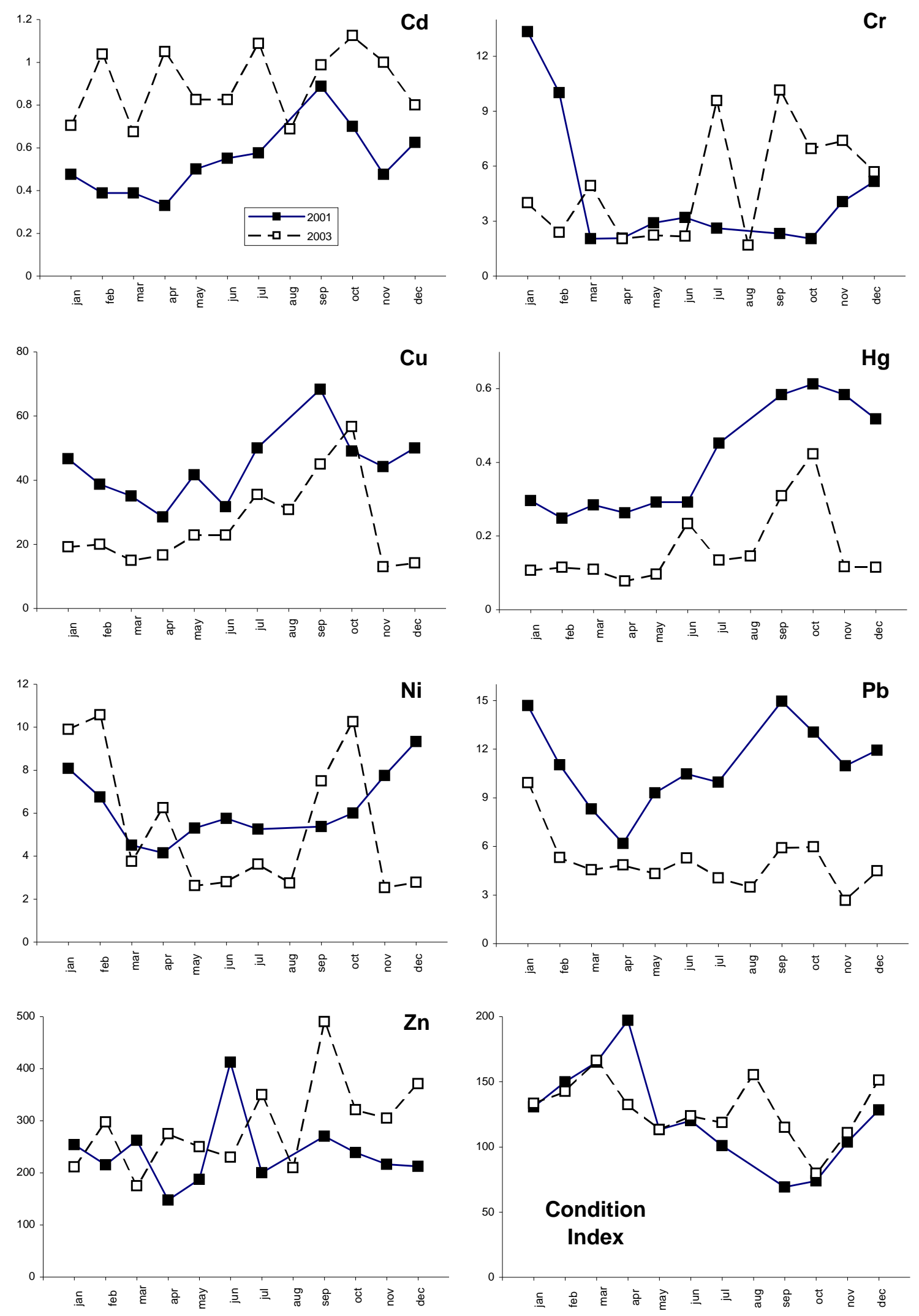

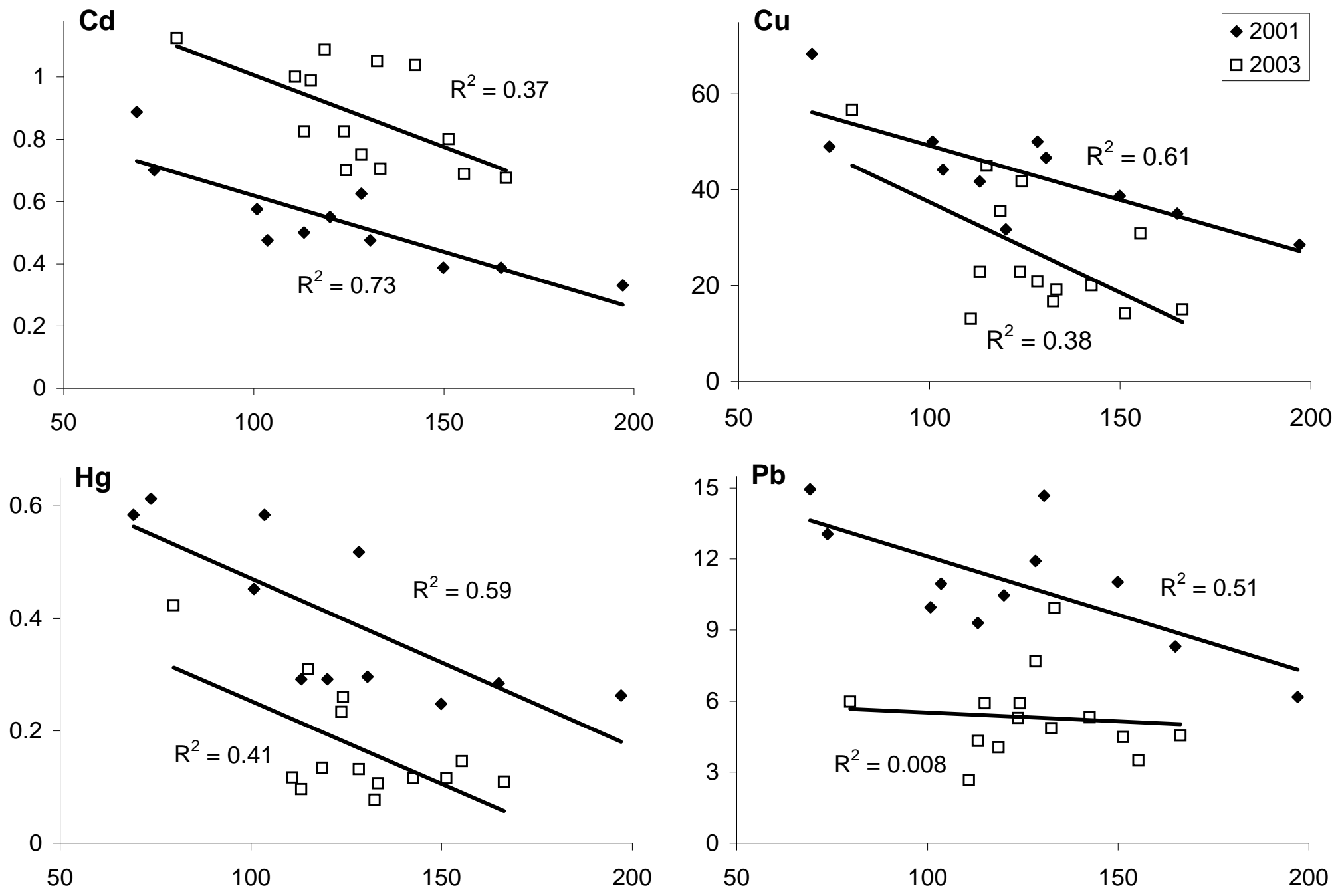
Click here to download Complete Manuscript (text, tables, and figures): Table 1.doc

Table 1

\begin{tabular}{cccc}
\hline & Detection limit & Obtained value & Certified value \\
\hline $\mathrm{Cd}\left(\mu \mathrm{g} \mathrm{g}^{-1}\right)$ & 0.02 & $0.34 \pm 0.01$ & $0.35 \pm 0.01$ \\
$\mathrm{Cr}\left(\mu \mathrm{g} \mathrm{g}^{-1}\right)$ & 0.06 & $0.71 \pm 0.04$ & $0.78 \pm 0.068$ \\
$\mathrm{Cu}\left(\mu \mathrm{g} \mathrm{g}^{-1}\right)$ & 0.3 & $9.4 \pm 0.1$ & $9.2 \pm 0.2$ \\
$\mathrm{Hg}\left(\mu \mathrm{g} \mathrm{g}^{-1}\right)$ & 0.007 & $0.20 \pm 0.01$ & $0.20 \pm 0.01$ \\
$\mathrm{Ni}\left(\mu \mathrm{g} \mathrm{g}^{-1}\right)$ & 0.09 & $2.5 \pm 0.2$ & $2.3 \pm 0.3$ \\
$\mathrm{~Pb}\left(\mu \mathrm{g} \mathrm{g}^{-1}\right)$ & 0.2 & $1.98 \pm 0.09$ & $2.00 \pm 0.04$ \\
$\mathrm{Zn}\left(\mu \mathrm{g} \mathrm{g}^{-1}\right)$ & 3 & $82 \pm 2$ & $83 \pm 2$ \\
\hline
\end{tabular}

